\title{
Treatment Effect of Licorice and Frankincense Eldakr from Pneumonia Induced by Bacterial Liposaccharides in Rats
}

\author{
Safaa M. Faid \\ Department of Home Economics, Faculty of Specific Education, Ain Shams \\ University, Cairo, Egypt \\ E mail: $\underline{\text { dr safaa2010@yahoo.com }}$
}

\begin{abstract}
Acute lung injury is a serious illness with a high death rate, resulting in more significant diseases. Thus, this study evaluated the licorice extract for flavonoid compounds and frankincense extract for the essential oil to treat pneumonia in experimental animals. The results found that the major flavonoid compounds in licorice extract were Rutin, Quercetin-3-O-glucoside, Vitexin, and Apigenin-7-O- $\beta$-glucoside, whilst, Narengin, Quercetin, Luteolin-7-O- $\beta$ glucoside, and Epicatechin were found in medium amounts. Furthermore, it could be noticed the licorice extract contained antioxidant activity which scavenging free radicals. Meanwhile, Frankincense oil could be identified and the major compounds were $\propto$ - Pinene, Limonene, $\propto$ - Campholenal, and $\beta$ Fenchene whilst, P-Cymene, $\propto-$ Thujene, Octanal, and Sabinene were found in medium amounts.

The biological experiment observed that the male rats were divided into five groups; the first group was considered a negative control. The rest were injected with $50 \mathrm{mg} / \mathrm{kg}$ of lipopolysaccharide (LPS) to cause pneumonia, after that, re-divided the rat groups. The second group considered as a positive control group, while the 3 and 4 groups were taken orally/day separately 200 $\mathrm{ppm} / \mathrm{kg} \mathrm{BW}$ rat from each licorice and frankincense, and group 5 was taken orally/ day 200ppm from both licorice and frankincense aqueous extract was for four weeks during the experimental period. The results found that group 5 which was taken orally/ day 200ppm from both licorice and frankincense extract give the best results to improve the complete blood picture, inhibition of inflammation and oxidative stress, followed by the groups were taken orally/day separately $200 \mathrm{ppm} / \mathrm{kg}$ BW rat /day from each licorice and frankincense, respectively. The result could be recommended to use the licorice and frankincense extract as a new curative agent for treating the pneumonia of rats induced by bacterial liposaccharides.
\end{abstract}

Key words: Licorice, Frankincense, liposaccharides, pneumonia, flavonoids compounds, essential oil 


\section{INTRODUCTION}

Acute lung injury (ALI) is the damage of structure and serious oxidation disorders caused by various pathogens, exhibited clinical syndrome, such as respiratory distress and dispersive lung infiltration ( $\mathbf{L v}, 2016)$. Acute lung injury (ALI) and acute respiratory distress syndrome (ARDS), are described by great hypoxemia, pulmonary edema, and neutrophil accumulation in the lung, which is the prominent source of diseases and mortality in critically disease patients (Yu et al., 2015).

Lipopolysaccharide (LPS) is a bacterial endotoxin derived from Gramnegative bacteria. It is also an experiential promoter of acute lung injury (ALI) completely during a week (Meng et al., 2015). This process is followed by the development of lung fibrosis (Moore et al., 2013). It is activated by stimulating the immune system in a manner similar to severe sepsis by causing systemic inflammation with the production of Reactive Oxygen Species (ROS), which begins to injure the lung tissue by oxidative oxidation of the pulmonary blood vessels. (Sabarirajan et al., 2010). This injury ends with severe hypoxemia and inflammatory cell infiltration (Al-Harbi et al., 2015). The cell infiltration begins in the capillaries and then in the interstitial tissue and is accompanied by the enlargement of the interstitial fibroblasts. By the time, the defect caused by the tissues and tissue trauma ends with fibrosis (Matuschak and Lechner, 2010).

Licorice is an important medicinal substance widely utilized in clinical practice, as it has contained more than 20 triterpenoids and 300 flavonoids. Chalcone, one of the main classes of flavonoids, has a variety of biological activities. Licorice extract has a wide range of pharmacological activities such as anti-inflammatory, antioxidative, anticancer, anti-microorganisms, lowering glucose in the blood, prevention of acute lung injury, heart and liver activities (Wang et al., 2020 \& Editorial, 2020).

Frankincense has several mechanisms, by inhibiting leukotriene synthesis, cyclooxygenase and lipoxygenase, and oxidative stress, and by regulating immune cells from the innate and acquired immune system. Clinical trials have demonstrated the efficacy of frankincense and its phytochemical against osteoporosis, multiple sclerosis, and asthma. Frankincense showed beneficial influences on brain tumor-related edema that may be a desirable improvement (Efferth and Oesch, 2020).

The aim of this study was to study the treatment role of licorice and frankincense Eldakr on lipopolysaccharide-induced lung inflammatory. 


\section{Materials}

\section{MATERIALS AND METHODS}

Licorice (Glycyrrhiza glabra L.) and frankincense Eldakr (Boswellia serrata L.) were purchased from the local market, Cairo, Egypt.

Dried licorice and frankincense were extracted separately in 80\% ethanol $(100 \mathrm{~g} / \mathrm{L})$ by maceration for 72 hours. The extract was filtered using Whatman No1 filter paper. The filtrate was evaporated to concentrate in a rotary evaporator and then stored at $4{ }^{\circ} \mathrm{C}$ until use (Darwish et al., 2018).

Kits for determination of all hematological and antioxidant parameters were purchased from Sigma-Aldrich Corp., MO, for use in analysis. Also, cytokines kits were obtained from enzyme-linked immunosorbent assay (ELISA) kits (R\&D systems, Minneapolis, MN, USA). Lipopolysaccharide (LPS) (Escherichia coli LPS) purchased from Sigma Aldrich (St. Louis, MO, USA) in phosphate-buffered saline obtained from Sigma Aldrich.

Thirty healthy Sprague-Dawley albino rats weight (200-220g) were purchased from National Organization for Drug and Control Research, Giza, Egypt and they were kept under observation for one week before experiment and fed on the basal diet for growing rats according to Pell et al., (1992).

\section{Methods:}

\section{Estimation of antioxidant activity from licorice extract}

The total phenolic content in the licorice extract was measured using the method of Qawasmeh et al., (2012) with Folin-Ciocalteu reagent. Gallic acid was used as standard $(1 \mathrm{mg} / \mathrm{ml})$ and the results were expressed as gallic acid equivalents (GAE $\mathrm{mg} / \mathrm{g}$ of dry weight). The total flavonoids content was determined by the method of Eghdami and Sadeghi, (2010). The absorbance was measured against a blank solution at $510 \mathrm{~nm}$ and the total flavonoids content was expressed in terms of milligrams of quercetin equivalent per gram dry weight (mg QE /g of dry weight).

\section{Determination of $\mathrm{O}_{2}{ }^{\bullet-}$, DPPH ${ }^{\circ}$ and FRAP radical solutions}

The capability of extracts to neutralize superoxide anion $\left(\mathrm{O}_{2} \bullet-\right)$ scavenger capacity formed by the reduction of nitroblue tetrazolium (NBT) with NADH mediated by phenazine methosulfate (PMS) under aerobic conditions was conducted according to Cos et al., (1998). The percentage of inhibition I (\%) for each radical species was calculated using the following equation: $\mathrm{I}(\%)=100 \times(\mathrm{A}$ blank $-\mathrm{A}$ sample $) / \mathrm{A}_{\text {blank, }}$, where $\mathrm{A}$ blank was the absorbance of the control reaction and $\mathrm{A}$ sample was the absorbance of the examined samples, corrected for the value of the blank probe. From the obtained I (\%) values, the $\mathrm{IC}_{50}$ values (which represented the concentrations of the examined extracts that caused $50 \%$ neutralization) were determined by linear regression analysis, using Origin software, version 9.0.The DPPH• was 
prepared and determined according to Jena et al., (2017). The percentage inhibition of the DPPH radical was calculated according to the equation:

DPPH scavenging $\%=[\{(A \mathrm{C}-A \mathrm{~T}) / A \mathrm{C}\} \times 100]$

Where $A \mathrm{C}=$ Absorbance of the control at $\mathrm{t}=0 \mathrm{~min}$

$A \mathrm{~T}=$ absorbance of the sample $+\mathrm{DPPH}$ at $\mathrm{t}=16 \mathrm{~min}$

From the obtained I (\%) values, the $\mathrm{IC}_{50}$ values (which represented the concentrations of the examined extracts that caused $50 \%$ neutralization) were determined by linear regression analysis, using Origin software, version 9.0.

To evaluate the reducing power of extract, the ferric ion reducing antioxidant power (FRAP) determined as described by Benzie and Strain, (1996). Mean values of reducing power were expressed as milligrams of ascorbic acid equivalents (AAE) per gram of dry weight of extract calculated according to the standard calibration curve.

\section{Determination of flavonoids fraction from licorice extract}

High-Performance Liquid Chromatography (HPLC) technique was used for separation and estimation of flavonoids compounds in licorice extract was determined according to the method described by Madrigal-Carballob et al., (2009). HPLC instrument (Hewlett Packard series 1100 HP) Column hypersil BDS $5 \mu \mathrm{m} \mathrm{C} 18$ and Detector UV $254 \mathrm{~nm}$.

\section{Essential oil extraction from frankincense:}

Frankincense was hydro-distilled for $3 \mathrm{~h}$ in a Clevenger type apparatus according to the European Pharmacopoeia (Council of Europe, 1997). The obtained oil was subsequently dried over anhydrous $\mathrm{Na}_{2} \mathrm{SO}_{4}$ and kept at $4{ }^{\circ} \mathrm{C}$ until analysis.

\section{Gas Chromatography - Mass Spectral Analysis}

The essential oil of frankincense was analyzed by gas chromatography mass spectral (GC-MS) according to method described in Ali et al., (2014). GC-MS analyses on an Agilent system consisting of a model 6890 Gas Chromatograph, a model 5973 Mass Selective Detector (MSD) and an Agilent Chem Station Data system.

\section{Biological experiment}

Experimental male rats were fed on a basal diet for 7 days and randomly divided into five groups six rats of each. The $1^{\text {st }}$ main group was fed on a basal diet for another 4 weeks and considered as control negative rats. The rest of the rats were injected with $50 \mathrm{mg} / \mathrm{kg}$ of lipopolysaccharide (LPS) by intraperitoneal (IP) injection to induce pneumonia according to Lee et al., (2019), after that, redivided the rest group. The second group considered as a positive control group was also fed the basal diet only, while the 3 and 4 groups were fed basal diets and taken orally separately $200 \mathrm{ppm} / \mathrm{kg}$ bw rat /day from each licorice and frankincense and group 5 was fed basal diets and taken 200ppm from both 
licorice and frankincense aqueous extract was together taken orally by stomach tube for four weeks during the experimental period.

At the end of experimental, the blood samples were taken with drawn from the orbital plexus and centrifuged at $3000 \mathrm{rpm}$ to obtain the sera after that, the sera were kept in a deep - freezer at $-20^{\circ} \mathrm{C}$ until their analysis.

Complete blood of picture as blood hemoglobin $(\mathrm{Hb})$, hematocrite $(\mathrm{Ht})$ and platelets were determined using a whole blood sample and the method described by Dacie and Lewis, (1984), respectively. Red blood cells (RBCs) and white blood cells (WBCs) were measured as recommended by Riley, (1960).

Serum lipid peroxidation was determined calorimetrically as malondialdehyde (MDA) by Yoshioka et al., (1979). Moreover, the activity of the antioxidant enzymes, superoxide dismutase (SOD) was measured in the serum according to the method of Sairam et al,. (2003), non-enzyme Glutathione (GSH) was measured in the serum by Habig et al., (1974). Moreover, the activity of the antioxidant enzymes, Catalase (CAT) was measured according to the method of Aebi, (1995).

Serum selected cytokines as interleukin-1 $\alpha$ (IL-1 $\alpha$ ), interleukin-6 (IL-6) were determined according to Kandir and Keskin, (2016) and tumor necrotic factor- $\alpha$ (TNF- $\alpha$ ) was determined according to Millena et al., (2004).

\section{Statistical analysis}

The obtained data were exposed to the analysis of variance. Duncan's multiple range tests at $(P \leq 0.05)$ level was used to compare between means. The analysis was carried out using the ANOVA procedure of Statistical Analysis System (SAS, 2004).

\section{RESULTS AND DISCUSSION Antioxidant and its activity in licorice extract}

Polyphenols play a vital role as antioxidant materials which would be the ability to prevent harmful oxidation by scavenging free radicals due to their hydroxyl groups. Therefore, the results In Table (1) revealed that the total phenolic content (TPC) and flavonoids content of licorice aqueous extract had contained $15.59 \mathrm{mg} \mathrm{GAE} / \mathrm{g}$ and $10.92 \mathrm{mg} \mathrm{QE} / \mathrm{g}$, respectively. Polyphenols act as antioxidants and thus contribute to the relief of a great range of chronic diseases, like cancer, diabetes, skin damage, allergies, atherosclerosis, and viral infections (Huang and Shen, 2012).

The results from the same Table showed that the antioxidant capacity (IC50 value) as determined by DPPH scavenging activity assay and Superoxide anion (O2-) from licorice extract was found to be good (25.11and 35.86 $\mu \mathrm{g} / \mathrm{ml})$, meanwhile, FRAP activity was $55.28 \mathrm{mg} / \mathrm{g}$ ascorbic acid equivalents 
(AAE). Furthermore, Sultana et al., (2007a,b) reported that the great activity of the radical scavenging activity of DPPH referred to as the presence of greater levels of total phenols and flavonoids for the reason that they play the main role as a proton-donating and can act as free radical inhibitors, and may act as an antioxidant.

Phenolic compounds like flavonoids, alkaloids, tannins, and saponins present in licorice extract had contained natural antioxidant activity (Fangliang et al., 2020). It could be concluded that the licorice aqueous extract can be utilized as a high source of natural antioxidants in scavenging oxidative harmful in the human body.

Table (1): Antioxidant and its activity in licorice extract

\begin{tabular}{|c|c|}
\hline Antioxidant and its activity & Licorice extract \\
\hline$*$ Total phenolic content $(\mathrm{TPC})$ & $15.59 \pm 0.51$ \\
\hline$* *$ Total flavonoids compounds & $10.92 \pm 0,43$ \\
\hline$* * *$ DPPH scavenging activity $\left(\mathrm{IC}_{50}\right)$ & $25.11 \pm 0.62$ \\
\hline$* * * *$ Superoxide anion $\left(\mathrm{O}_{2} \bullet-\right)$ & $35.86 \pm 0.81$ \\
\hline FRAP**** & $55.28 \pm 0.94$ \\
\hline
\end{tabular}

Data represented in means of duplicates \pm standard deviation.

*Total phenolic was expressed as gallic acid equivalents (GAE) $\mathrm{mg} / \mathrm{g}$ sample ** expressed as quercetin equivalents $(\mathrm{QE}) \mathrm{mg} / \mathrm{g} * * *$ Inhibitory concentration at which $50 \%$ of DPPH radical is scavenged $\mathrm{IC}_{50}(\mu / \mathrm{ml})^{* * * *}$ Inhibitory concentration at which Inhibitory concentration at which $50 \%$ of $\left(\mathrm{O}_{2} \bullet-\right)$ radical is scavenged $\mathrm{IC}_{50}(\mu / \mathrm{ml})$ :. ***** FRAP expressed as milligrams of ascorbic acid equivalents (AAE) per gram of dry weight

\section{Fractionation flavonoids fraction from licorice extract}

The flavonoids compounds from licorice extract were fractionated using HPLC and the results are reported in Table (2). From the results it could be found that thirty compounds from licorice extract could be identified to the major compound was found as Rutin, Quercetin-3-O-glucoside, Vitexin, and Apigenin-7-O- $\beta$-glucoside $(32.0,29.0,28.0$, and $25.0 \mathrm{mg} / 100 \mathrm{~g}$ ), whilst, the compounds, Narengin, Quercetin, Luteolin-7-O- $\beta$-glucoside, and Epicatechin had contained medium amounts 18.0, 17.0, 15.0 and $13.0 \mathrm{mg} / 100 \mathrm{~g}$, respectively. Moreover, Kaempherol-7-O-glucoside, Kampferol, Apegnin, Luteolin, and Myricetin as manor compounds had concentrated 4.36, 3.40, 2.41, $9.0,7.0$, and $5.0 \mathrm{mg} / 100 \mathrm{~g}$, respectively. These results are in agreement with Siracusa et al., (2011) who found the most well-known flavonoids like rutin, quercetin, lutein, naringenin, kaempferol-7-O-glucoside in licorice has been discovered in previous reports but not quantified. These compounds were found as an antioxidant, anti-inflammatory, and anticancer activity. 
Table (2): Flavonoids content (mg/100g) from licorice extract

\begin{tabular}{|c|c|}
\hline Flavonoid compounds & Flavonoids $(\mathrm{mg} / 100 \mathrm{~g})$ \\
\hline Apegnin & 5.00 \\
\hline Narengin & 18.00 \\
\hline Luteolin & 6.00 \\
\hline Kampferol & 7.00 \\
\hline Rutin & 32.00 \\
\hline Quercetin & 17.00 \\
\hline Myricetin & 4.00 \\
\hline Epicatechin & 13.00 \\
\hline Vitexin & 28.0 \\
\hline Apigenin-7-O- $\beta$-glucoside & 25.00 \\
\hline Luteolin-7-O- $\beta$-glucoside & 15.00 \\
\hline Kaempherol-7-O-glucoside & 9.00 \\
\hline Quercetin-3-O-glucoside & 29.00 \\
\hline
\end{tabular}

\section{Quantification and identification of frankincense essential oil}

From the results in Table (3), it could be noticed that twelve compounds of frankincense oil could be identified and the major four compounds were found as $\propto$ - Pinene, Limonene, $\propto$ - Campholenal, and $\beta$-Fenchene (15.0, 12.0, 11.0 , and $10.0 \mathrm{mg} / 100 \mathrm{~g}$ ) beside four medium compounds, P-Cymene, $\propto-$ Thujene, Octanal and Sabinene were contained amounts 8.0, 7.0, 6.0 and 5.0 $\mathrm{mg} / 100 \mathrm{~g}$, respectively. Meanwhile, Ritenol acetate, trans-Pinocarveol, Terpinene and Tricyclene as four manor compounds had concentrated 4.0, 3.0, 2.0 , and $1.0 \mathrm{mg} / 100 \mathrm{~g}$, respectively. These results are in agreement with Kohoude et al. (2017) who observed that the essential oils of Boswellia dalili have a large proportion of $\alpha$-Pinene, although other main components in those oils like $\delta$-3-carene, $\alpha$-terpinene, and p-cymene were shown in lower amounts in the oleoresin essential oil. Boswellia dalzielii had contained a high amount of monoterpenes, particularly $\alpha$-pinene. A-pinene dominates the essential oils of Boswellia species, in addition, lower amounts of $\alpha$-thujene, limonene, myrcene, sabinene, and P-cymene (DeCarlo et al., 2018).

Table (3): Identification of essential oils from frankincense

\begin{tabular}{|c|c|}
\hline Identification & Essential Oil (mg/100g) \\
\hline$\propto-$ Thujene & 7.00 \\
\hline$\propto-$ Pinene & 15.00 \\
\hline$\beta$-Fenchene & 10.00 \\
\hline P-Cymene & 8.00 \\
\hline Limonene & 12.00 \\
\hline Sabinene & 5.00 \\
\hline$\propto-$ Campholenal & 11.00 \\
\hline trans-Pinocarveol & 3.00 \\
\hline Terpinene & 2.00 \\
\hline Tricyclene & 1.00 \\
\hline Octanal & 6.00 \\
\hline Ritenol acetate & 4.00 \\
\hline
\end{tabular}




\section{Effect of Licorice and Frankincense and both on hematological in pneumonia of rats induced by bacterial liposaccharides}

Hematological analysis was determined in different rat groups treated with licorice, frankincense, and both compared with the control rat health group and the results are reported in Table (4). From the results it could be observed that the lowest hemoglobin $(\mathrm{Hg})$, hematocrit value (Ht), red blood cells (RBCs), and white blood cells (WBCs) in rats control positive (group 2) fed on basal diet were $6.8 \mathrm{~g} / \mathrm{dl}, 20.1 \%, 2.11106 / \mu 1$, and $7.91103 / \mu 1$, respectively, compared with the highest healthy rats group was $13.8 \mathrm{~g} / \mathrm{dl}, 45.1 \%, 4.48106 / \mu 1,12.4710^{3} / \mu 1$, respectively.

The hematological analysis in rats group 5 was received daily basal diet and taken orally/day licorice $100 \mathrm{ppm}$ plus frankincense $100 \mathrm{ppm}$ the highest was $12.5 \mathrm{~g} / \mathrm{dl}, 44.05 \%, 4.2510^{6} / \mu 1$, and $11.8710^{3} / \mu 1$, followed by the rats' group fed on basal diet and taken orally/ day $200 \mathrm{ppm}$ from licorice extract was 11.1 $\mathrm{g} / \mathrm{dl}, 40.2 \%, 3.8510^{6} / \mu 1$, and $10.7610^{3} / \mu 1$, respectively. Moreover, the rat group 4 has daily received basal diet plus Frankincense 200ppm extract was given orally was $9.9 \mathrm{~g} / \mathrm{dl}, 35.1 \%, 3.1510^{6} / \mu \mathrm{l}$, and $9.3510^{3} / \mu 1$, respectively.

The greatest considerable in erythrocytes and hematocrit counts after oral management of an extract from licorice and frankincense and both may be due to the extract had contained phytochemicals that carried out the secretion of erythropoietin in the stem cells of healthy rats. Erythropoietin is a glycoprotein hormone that encourages stem cells in the bone marrow to produce red blood cells (Ohlsson and Aher, 2009). Erythropoietin impacts the blood's ability to carry oxygen and the amount of oxygen delivered to tissues for the reason, that red blood cells and hemoglobin are important in transporting respiratory gases (Oyedeji and Bolarinwa, (2013).

Table (4): Influence of Licorice and Frankincense and both on some hematological parameters in pneumonia of rats induced by bacterial liposaccharides

\begin{tabular}{|c|c|c|c|c|}
\hline Groups & $\mathrm{Hb}(\mathrm{g} / \mathrm{dl})$ & $\mathrm{Ht}(\%)$ & $\begin{array}{c}\text { RBCs } \\
\left(10^{6} / \mu \mathrm{L}\right)\end{array}$ & $\begin{array}{c}\mathrm{WBCs} \\
\left(10^{3} / \mu \mathrm{L}\right)\end{array}$ \\
\hline Control negative (G1) & $13.8 \pm 0.43^{\mathrm{a}}$ & $45.1 \pm 0.4^{\mathrm{a}}$ & $4.48 \pm 1.8^{\mathrm{a}}$ & $12.47 \pm 0.03^{\mathrm{a}}$ \\
\hline Control positive (G2) & $6.8 \pm 0.14^{\mathrm{d}}$ & $20.1 \pm 0.17^{\mathrm{d}}$ & $2.11 \pm 0.25^{\mathrm{c}}$ & $7.91 \pm 0.03^{\mathrm{d}}$ \\
\hline Licorice 200 ppm (G3) & $11.1 \pm 0.86^{\mathrm{b}}$ & $40.2 \pm 1.15^{\mathrm{b}}$ & $3.85 \pm 0.43^{\mathrm{b}}$ & $10.76 \pm 0.05^{\mathrm{b}}$ \\
\hline Frankincense 200 ppm (G4) & $9.9 \pm 0.78^{\mathrm{c}}$ & $35.1 \pm 0.51^{\mathrm{c}}$ & $3.15 \pm 0.57^{\mathrm{b}}$ & $9.35 \pm 0.06^{\mathrm{c}}$ \\
\hline $\begin{array}{c}\text { Licorice 100 ppm + } \\
\text { Frankincense 100ppm (G5) }\end{array}$ & $12.5 \pm 0.73^{\mathrm{a}}$ & $44.5 \pm 2.49^{\mathrm{a}}$ & $4.25 \pm 0.76^{\mathrm{a}}$ & $11.87 \pm 0.04^{\mathrm{a}}$ \\
\hline
\end{tabular}

All values are mean \pm standard deviation $(n=3)$. Values in the same column with different letters are significant at $P \leq 0.05$ 
Effect of Licorice and Frankincense and both on antioxidants in pneumonia of rats induced by bacterial liposaccharides

The antioxidant enzymes and the malondialdehyde (MDA) were determined in different rats groups treated with Licorice and Frankincense and both and compared with the control rat health group and the results are reported in Table (3). The results showed that the rats control positive was the lowest in all parameters by $10.65,6.28$, and $4.08 \mathrm{U} / \mathrm{L}$ and also, MDA was the highest by $315.27 \mathrm{nmol} / \mathrm{ml}$, respectively, and the rats control negative group was the highest in all antioxidant enzymes (20.36, 14.38 and $7.53 \mathrm{U} / \mathrm{L}$ ) and also, the lipid peroxidation as malondialdehyde (MDA) was the lowest by $180.68 \mathrm{nmol} / \mathrm{ml}$, respectively.

The rats' groups were taken orally $200 \mathrm{ppm}$ of an extract from licorice and frankincense and both were increased the antioxidant defense, that is, enzymes glutathione (GSH), superoxide dismutase (SOD), and catalase (CAT), increased significantly, whereas, a significant decrease in lipid peroxidation as malondialdehyde (MDA). Moreover, the results reported that the licorice had contained high amounts of flavonoids and phenolic acid, meanwhile, frankincense was the highest in essential oil. When the rats fed on basal diet and taken orally/ day 100ppm from licorice plus $100 \mathrm{ppm}$ from frankincense give the best results followed by 200ppm from Licorice and $200 \mathrm{ppm}$ from frankincense in rat inducted with acute lung inflammation. These results confirm with Chen et al., (2017) which reported that polyphenols elevate the antioxidant enzymes containing superoxide dismutase (SOD), catalase (CAT), and glutathione peroxidase (GPx) proteins which related to antioxidant mechanisms. Pulmonary damage caused by a great in lipid peroxidation may be due to free oxygen radicals and lowering in antioxidant factors. Previous research found that elevated the amount of malondialdehyde (MDA) in animal lungs, decreased levels of both enzymatic and non-enzymatic antioxidants, and caused severe DNA damage (Afsar et al., 2018).

Table (5): Influence of Licorice and Frankincense and both on antioxidant and oxidative stress in pneumonia of rats induced by bacterial liposaccharides

\begin{tabular}{|c|c|c|c|c|}
\hline Groups & $\begin{array}{c}\text { GSH } \\
(\mathrm{U} / \mathrm{L})\end{array}$ & $\begin{array}{c}\text { SOD } \\
(\mathrm{U} / \mathrm{L})\end{array}$ & $\begin{array}{c}\text { CAT } \\
(\mathrm{U} / \mathrm{L})\end{array}$ & $\begin{array}{c}\mathrm{MDA} \\
(\mathrm{nmol} / \mathrm{ml})\end{array}$ \\
\hline Control negative (G1) & $20.36^{\mathrm{a}}$ & $14.38^{\mathrm{a}}$ & $7.53^{\mathrm{a}}$ & $180.68^{\mathrm{d}}$ \\
& \pm 1.73 & \pm 0.77 & \pm 0.08 & \pm 4.53 \\
\hline Control positive (G2) & $10.65^{\mathrm{d}}$ & $6.28^{\mathrm{d}}$ & $4.08^{\mathrm{d}}$ & $315.27^{\mathrm{a}}$ \\
& \pm 0.95 & \pm 0.47 & \pm 0.07 & \pm 7.25 \\
\hline Licorice 200 ppm (G3) & $17.59^{\mathrm{b}}$ & $12.56^{\mathrm{b}}$ & $6.39^{\mathrm{b}}$ & $200.53^{\mathrm{c}}$ \\
& \pm 1.05 & \pm 1.04 & \pm 0.05 & \pm 2.19 \\
\hline Frankincense 200 ppm (G4) & $14.67^{\mathrm{c}}$ & $10.39^{\mathrm{c}}$ & $5.48^{\mathrm{c}}$ & $220.75^{\mathrm{b}}$ \\
& \pm 0.98 & \pm 0.85 & \pm 0.01 & \pm 2.38 \\
\hline Licorice 100 ppm + & $19.72^{\mathrm{a}}$ & $13.94^{\mathrm{a}}$ & $7.11^{\mathrm{a}}$ & $185.28^{\mathrm{d}}$ \\
Frankincense 100 ppm (G5) & \pm 1.28 & \pm 0.91 & \pm 0.03 & \pm 1.58 \\
\hline
\end{tabular}

All values are mean \pm standard deviation $(n=3)$. Values in the same column with different letters are significant at $P \leq 0.05$ 


\section{Effect of Licorice and Frankincense and both on the levels of cytokines in pneumonia of rats induced by bacterial liposaccharides}

Table (6) showed the effect of licorice and frankincense and both on the cytokines TNF- $\alpha$, IL-1 $\alpha$, and IL- 6 in pneumonia of rats induced by bacterial liposaccharides. From the results, it could be observed that the TNF- $\alpha$, IL-1 $\alpha$, and IL-6 were the highest in control positive group rats inducted with pneumonia by $200.15,70.35$, and $75.39 \mathrm{pg} / \mathrm{mL}$, respectively. It is known that inflammation and oxidative stress play a vital influence in the pathogenesis of acute pneumonia. Different inflammatory mediators, like single-cell chemical protein 1 (MCP-1), tumor necrosis factor $-\alpha(\mathrm{TNF}-\alpha)$, and interleukin 16 (IL16), have been implicated in Lipopolysaccharide (LPS)-induced acute lung injury (Jing and Chunhua, 2015).

The control healthy rats fed on basal diet were the lowest in the level cytokines by $75.38,10.25$, and $15.18 \mathrm{pg} / \mathrm{ml}$, respectively. In addition, the effect of licorice and frankincense and both on the pneumonia of rats, the results reported that the rat group taken orally/ day with licorice 100ppm extract plus $100 \mathrm{ppm}$ frankincense extract was the lowest and nearly control healthy rats group by $59.61,78.28$, and $73.33 \%$, respectively followed by rats group taken orally/ day with Licorice 200ppm extract was 39.78, 63.91, and 60.21\%, respectively. Meanwhile, the rats group taken orally/ day with $200 \mathrm{ppm}$ Frankincense extract was decreased by $25.00,49.50$, and $45.70 \%$, respectively. These decreases in treatment rat groups may be able to be the licorice is widely utilized in folk medicine to treat many ailments such as infection and inflammation. The Licorice has been shown to have performed antiinflammatory activity. In acute lung injury models, it is inhibition NF- $\kappa B$ activation, phosphorylation, and extracellular regulated protein kinesis (ERK) may be due to the Licorice contains Coumadin's and flavonoids compounds all these compounds are responsible for the pharmacological activity of licorice (Salim et al., 2018). Moreover, Frankincense is an aromatic gum resin that has been in circulation for thousands of years in order to treat infections, and today it is frequently distilled as an essential oil consisting largely of major compounds like $\alpha$-pinene, $\alpha$-thujene, limonene, sabinene, $\alpha$-Campholenal and p-cymene. (Johnson et al., 2019). 
Table (6): Influence of Licorice and Frankincense and both cytokines in neumonia of rats induced by bacterial liposaccharides

\begin{tabular}{|c|c|c|c|}
\hline \multirow{2}{*}{ Groups } & TNF- $\alpha$ & IL-I $\alpha$ & IL-6 \\
\cline { 2 - 4 } & \multicolumn{3}{|c|}{$\mathrm{pg} / \mathrm{mL}$} \\
\hline Control negative (G1) & $75.38^{\mathrm{d}} \pm 1.84$ & $10.25^{\mathrm{d}} \pm 0.91$ & $15.18^{\mathrm{d}} \pm 0.91$ \\
\hline Control positive (G2) & $200.15^{\mathrm{a}} \pm 3.27$ & $70.35^{\mathrm{a}} \pm 1.28$ & $75.39^{\mathrm{a}} \pm 1.63$ \\
\hline Licorice 200 ppm (G3) & $120.53^{\mathrm{c}} \pm 1.97$ & $25.19^{\mathrm{c}} \pm 0.28$ & $30.0^{\mathrm{c}} \pm 0.41$ \\
\hline Frankincense 200 ppm (G4) & $150.11^{\mathrm{b}} \pm 1.84$ & $35.53^{\mathrm{b}} \pm 0.31$ & $40.94^{\mathrm{b}} \pm 0.52$ \\
\hline $\begin{array}{c}\text { Licorice 100 ppm + Frankincense } \\
\text { 100ppm (G5) }\end{array}$ & $80.24^{\mathrm{d}} \pm 1.86$ & $15.28^{\mathrm{d}} \pm 0.94$ & $20.11^{\mathrm{d}} \pm 0.81$ \\
\hline
\end{tabular}

All values are mean \pm standard deviation $(\mathrm{n}=3)$. Values in the same column with different letters are significant at $P \leq 0.05$

\section{CONCLUSSION}

From the obviously results it could be concluded that the licorice extract had contained high amounts of flavonoids and utilized in folk medicine to treat many ailments. Meanwhile, Frankincense extract had consisted of the major compounds from the essential oil that was used for medicine in inflammation. Thus, could be used licorice and frankincense extract may treat the pneumonia of rats induced by bacterial liposaccharides, and also, inhibition of inflammation and oxidative stress, therefore, which could a new curative agent for the protection from acute pneumonia.

\section{REFERENCES}

Aebi, M.E. (1995): Catalase. In: Bergmeyer J, Grabl B.M (eds) Methods of Enzymatic Analysis vol. III. Enzymes oxidoreductases, 3rd ed. Weinheim: Verlag-Chemie:273-286.

Afsar T., Razak S., Almajwal A. and Khan M. R. (2018): Acacia hydaspica R. Parker ameliorates cisplatin induced oxidative stress, DNA damage and morphological alterations in rat pulmonary tissue,BMC Complementary and Alternative Medicine, 18: 49.

Al-Harbi N.O., Imam F. and Nadeem A. (2015): Riboflavin attenuates lipopolysaccharide-induced lung injury in rats. Toxicol Mech Methods; 25: 417-423. 
Ali A.A.N., Sharopov F.S., Al-kaf A.G., Hill G.M., Arnold N.and Al-Sokari S.S. (2014). Composition of essential oil from Tagetes minuta and its cytotoxic, antioxidant and antimicrobial activities. Natural Product Communications; 9:265-268.

Benzie I.F.F. and Strain J.J. (1996): The ferric reducing ability of plasma (FRAP) as a measure of "antioxidant power": The FRAP assay. Analytical Biochemistry 239, 70-76

Chen X., Liu Z., Meng R., Shi C. and Guo N. (2017): Antioxidative and anticancer properties of licochalcone A from licorice, Journal of Ethnopharmacology, 198: 331-337.

Cos P., Ying L., Calomme M., Hu J.P., Cimanga K., Poel B.V., Pieters L., Vlietinck A.J. and Berghe D.V. (1998): Structure-activity relationship and classification of flavonoids as inhibitors of xanthine oxidase and superoxide scavengers. J Nat Prod 61: 71-76.

Council of Europe (1997): European Pharmacopoeia, 3rd Ed., Council of Europe Press, Strasbourg, 121-122.

Dacie J. V. and Lewis S. M. (1984): Practical hematology. Churchill Living Stone. London and New York.

Darwish A.M.G., Hamad G. and El Sohaimy S.A. (2018): Nutritional profile, antioxidant and antimicrobial potentials of chia seeds (Salvia hispanica L.)", Journal of Food Science and Technology, 1-21.

DeCarlo A., Johnson S., Poudel A., Satyal P., Bangerter L.and Setzer W.N. (2018): Chemical variation in essential oils from the oleo-gum resin of Boswellia carteri: A preliminary investigation. Chem. Biodivers, 15, 1-5.

Efferth T. and Oesch F. (2020): Anti-inflammatory and anti-cancer activities of frankincense: Targets, treatments and toxicities, Seminars in Cancer Biology, $1-21$

Eghdami A. and Sadeghi F. (2010): Determination of total phenolic and flavonoids contents in methanolic and aqueous extract of Achilleamillefolium. Journal of Organic Chemistry, 2: 81-84.

Fangliang Y., Tiantian C., Yujing Z., Xitong L., Guoxiang S. and Zhenhong C. (2020): Quality assessment of licorice (Glycyrrhiza glabra L.) from different sources by multiple fingerprint profiles combined with quantitative analysis, antioxidant activity and chemometric methods", Food Chemistry , 324: 126854

Habig W.H. Pabst M.J. and Jacoby W.B. (1974): Glutathione $S$-transferases: the first enzymatic step in mercapturic acid formation. Journal Biological Chemictery, 249:7130-7139. 
Huang D.-W. and Shen S.C. (2012): Caffeic acid and cinnamic acid ameliorate glucose metabolism via modulating glycogenesis and gluconeogenesis in insulin-resistant mouse hepatocytes. Journal of Functional Foods, 4, 358-366.

Jena S., Ray A., Banerjee A., Sahoo A., Nasim N., Sahoo S., Kar B., Patnaik J., Panda P.C. and Nayak S. (2017): Chemical composition and antioxidant activity of essential oil from leaves and rhizomes of Curcuma angustifolia Roxb. Nat Product Res, 31:2188-2191

Jing W. and Chunhua M, (2015): Effects of acteoside on lipopolysaccharideinduced inflammation in acute lung injury via regulation of NF- $\kappa \mathrm{B}$ pathway in vivo and in vitro. Toxicol Appl Pharmacol; 285: 128-135.

Johnson S., DeCarlo A., Satyal P., Dosoky N.S., Sorensen A. and Setzer W.N. (2019): The Chemical Composition of Boswellia occulta Oleogum Resin Essential Oils, Natural Product Communications: 1-7.

Kandir S. and Keskin E. (2016):Serum IL-1 $\beta$, IL-6, IL-10 and TNF- $\alpha$ Levels in Thyroidectomized Rats, Kafkas Üniversitesi Veteriner Fakültesi Dergisi, 22 : 297-300.

Kohoude M.J., Gbaguidi F., Agbani P., Ayedoun M.A., Cazaux S.and Bouajila J. (2017): Chemical composition and biological activities of extracts and essential oil of Boswellia dalzielii leaves. Pharm. Biol., 55: 33-42.

Lee S.A., Lee S.H., Kim J.Y. and Lee W.S. (2019): Effects of glycyrrhizin on lipopolysaccharide-induced acute lung injury in a mouse model, J. Thorac. Dis., 11:1287-1302

Lv Q. (2016): Glucocorticoid combined with hyaluronic acid enhances glucocorticoid receptor activity through inhibiting p-38MAPK signal pathway activation in treating acute lung injury in rats. Eur Rev Med Pharmacol Sci; 20: 3920-3929.

Madrigal-Carballob S., Rodriguezb G., Kruegera C.G., Dreherc M. and Reed J.D. (2009): Pomegranate (Punica granatum) supplements: Authenticity, antioxidant and polyphenol composition, Journal of Functional Foods, 1: 324329.

Matuschak G.M. and Lechner A.J. (2010): Acute lung injury and the acute respiratory distress syndrome: pathophysiology and treatment. Mo Med; 107: 252-258.

Meng F., Mambetsariev I. and Tian Y. (2015): Attenuation of lipopolysaccharide- induced lung vascular stiffening by lipoxin reduces lung inflammation. Am J Respir Cell Mol Biol; 52: 152-161. 
Millena A.C., Reddy S.C., Bowling G.H. and Khan S.A. (2004): Autocrine regulation of steroidogenic function of Leydig cells by transforming growth factor-. Mol Cell Endocrinol, 224:29 -39.

Moore B., Lawson W.E. and Oury T.D. (2013): Animal models of fibrotic lung disease. Am J Respir Cell Mol Biol; 49: 167-179.

Ohlsson A. And Aher S.M. (2009):Early erythropoietin for preventing red blood cell transfusion in preterm and/or low birth weight infants. Journal of Dietary Supplements 6: 227-251.

Oyedeji K.O. and Bolarinwa A.F. (2013): Effect of Corchorus olitorius extract on haematological and plasma biochemical parameters in male albino rats. IOSR Journal of Dental and Medical Sciences (IOSR-JDMS) 5: 68-71.

Pell J.D., Gee J.M., Wortley G.M. and Johnson I.T. (1992): Both dietary corn oil and guar gum stimulate intestinal crypt cell proliferation in rats, by independent but potentially synergistic mechanisms. Journal Nutition, 122, 2447-2456

Qawasmeh A., Obied H. K., Raman A. and Wheatley W. (2012): Influence of fungal endophyte infection on phenolic content and antioxidant activity in grasses: Interaction between Loliumperenne and different strains of Neotyphodiumlolii. Journal of Agricultural and Food Chemistry, 60: 33813388.

Riley V. (1960): Adaptation of orbital bleeding technique to rapid serial blood studies. Proc. Soc. Exp. Biol. Med., 109 : 751-754.

Sabarirajan J., Vijayaraj P. and Nachiappan V. (2010): Induction of acute respiratory distress syndrome in rats by lipopolysaccharide and its effect on oxidative stress and antioxidant status in lung. Indian J Biochem Biophys; 47: $278-284$.

Sairam K., Priyambada S., Aryya N.C. and Goel R.K.(2003): Gastroduodenal ulcer protective activity of Asparagus racemosus: An experimental, biochemical and histological study, Journal Ethnopharmacology, 86: 1-6.

Salim S., Kalam M.A., Yusuf A., Khanday S., Shafi S. and Mohammad I. (2018): Asl-us-Sus (Glycyrrhiza glabra L.), a great munzij-i-balgham (concotive of phlegm) drug of Unani system of medicine: a review, International Journal of Unani and Integrative Medicine; 2(3): 16-19.

SAS (2004): Statistical Analysis System. SAS User's Statistics SAS Institute Inc. Editors, Cary, NC. 
Siracusa L., Saija A., Cristani M., Cimino F., D’Arrigo M., Trombetta D., Rao F.and Ruberto G. (2011): Phytocomplexes from liquorice (Glycyrrhiza glabra L.) leaves - chemical characterization and evaluation of their antioxidant, anti-genotoxic and anti-inflammatory activity. Fitoterapia 82: 546556.

Sultana, B., Anwar, F. and Przybylski, R. (2007a): Antioxidant activity of phenolic components present in barks of Azadirachta indica, Terminalia arjuna, Acacia nilotica, and Eugenia jambolana Lam. trees. Food Chem., 104: 11061114.

Sultana, B., Anwar, F. and Przybylski, R. (2007b): Antioxidant activity corncob extracts for stabilization of corn oil subjected to microwave heating. Food Chem., 104: 997- 1005.

Wang D., Liang J., Zhang J., Wang Y. and Chai X. (2020): Natural chalcones in Chinese materia medica: licorice. Evid. Based Complementry and Alternative Medicine, 1-14.

Yoshioka T., Kawada K., Shimada T. And Mori M (1979): Lipid peroxidation in maternal and cord blood and protective mechanism against activated-oxygen toxicity in the blood. American Journal Obstetrics Gynecolology,135: 372-376.

Yu J.L., Zhang X.S., Xue X. and Wang R.M. (2015): Patchouli alcohol protects against lipopolysaccharide-induced acute lung injury in mice. J Surg Res; 194: 537-543. 
الملخص العربى

\section{العرقسوس واللبان الاكر كمستخلصات للعلاج من الالتهاب الرئوي الناجم عن الليبوسكريا البكتيري في فئران التجارب من الاب}

يعتبرالالتهاب الرئوي هو مرض خطير مما يؤدى الى ارتفاع معدل الوفيات. لذلك اعدت هذه

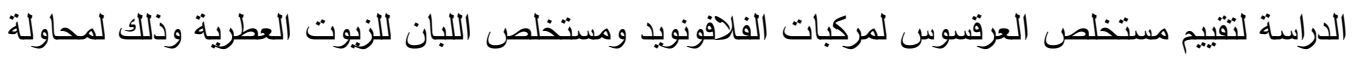
تقديم علاج من المستخلصات الطبيعية لعلاج الألتهاب الرئوى ، وقد أوضحت النقان النتائج أن مركبات

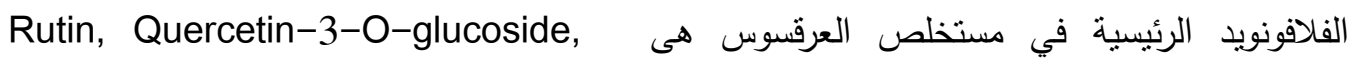
،Narengin ، Vيitexin, and Apigenin-7-O- $\beta$-glucoside,

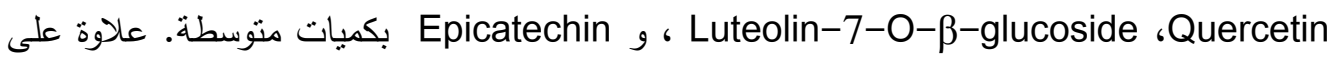
ذلك ، يمكن ملاحظة أن مستخلص العرقسوس يحتوي على نشاط مضاد للأكسدة يقضي على الجذور

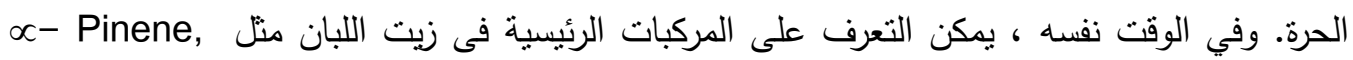
P- بجانب المركبات المتوسطة كانت Limonene, $\propto-$ - Campholenal, and $\beta$-Fenchene

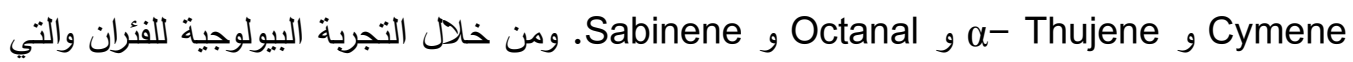

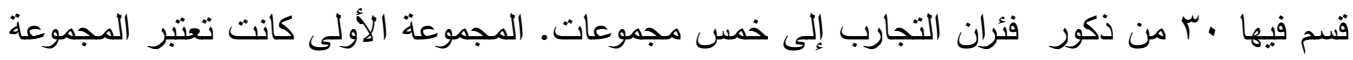

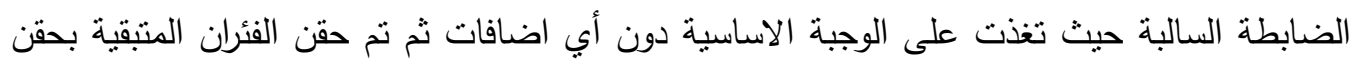

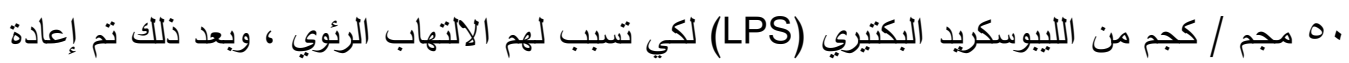

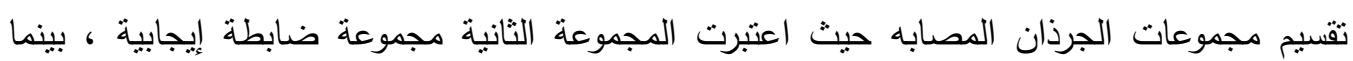

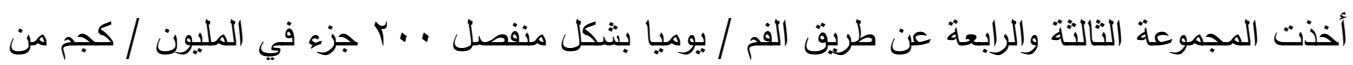

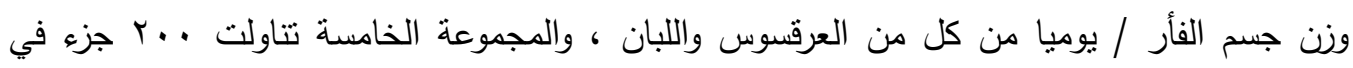

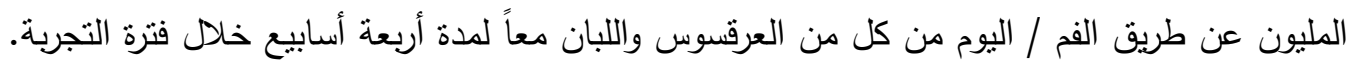

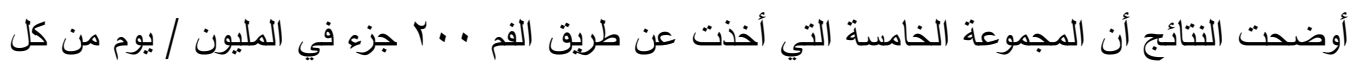

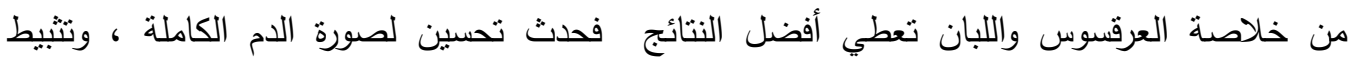

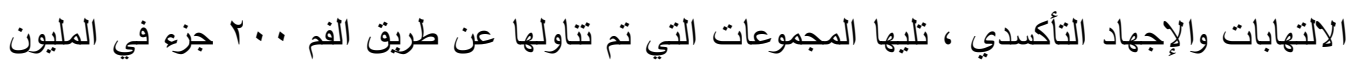

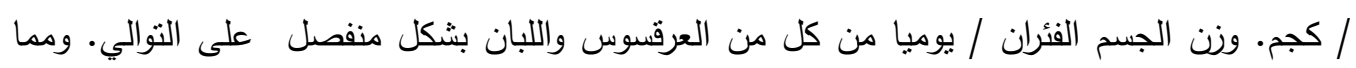

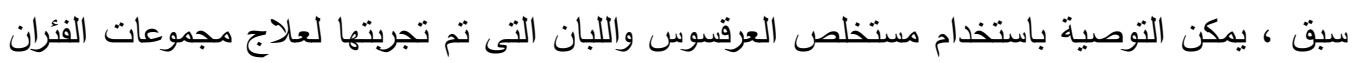

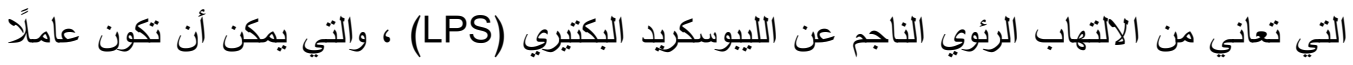
علاجيًا جديدًا للمساهمه في علاج الالتهاب لرئري النماب الرئوي.

الكلمات المفتاحية: العرقسوس- لبان الدكر - الليبوسكريد- المركبات الفينولية- الزيوت الاساسية 